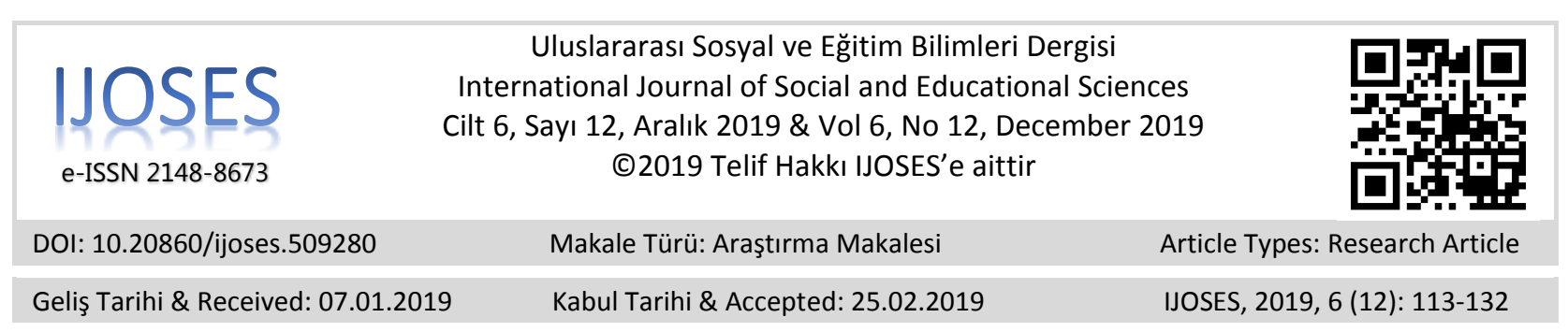

\title{
İkinci Dünya Savaşı Yıllarında Sosyal Bir Yardım Olarak Kızılay Așevleri*
}

Red Crescent Soup Kitchens as a Social Aid during the Second World War

\section{Ceren Utkugün** \& Şaban Ortak***}

$\ddot{\mathbf{O z}}$

1929 Dünya Ekonomik Krizinin etkileri devam ederken İkinci Dünya Savaşı başlamıştır. Bu durum savaşın olumsuz ekonomik etkilerinin daha yoğun biçimde yaşanmasına neden olmuştur. Savaş yıllarında askeri harcamaların artması, üretimin ve ithalatın azalması halkın üzerinde ağır bir ekonomik yük oluşturmuştur. Enflasyon toplumda ekonomik bunalım oluşturmuş, ekonomik güçlerin askeri alana kaydırılması tarımsal üretimde azalmalara yol açmış, besin maddeleri sıkıntısı sonucunda karne uygulamaları başlamış, yer yer kıtlık yaşanmıştır. İkinci Dünya Savaşı'nın başlamasıyla savaş dışı kalmaya çalışan Türkiye seferberlik ilan etmiştir. Seferberlik ilanı dış tehditlere karşı milli müdafaa tedbiri olarak değerlendirilse de sonuçları itibariyle ülkede iaşe sorunu yaşanmasına yol açmıştır.

Savaş yıllarında yaşanan ekonomik sıkıntıları hafifletmek amacıyla çeşitli ekonomik ve sosyal tedbirler alınmıştır. Ekonomik müdahalelerle savaş enflasyonu önlenmeye ve sosyal politikalarla savaştan kaynaklanan toplumsal sorunlar hafifletilmeye çalışılmıştır. Sosyal politika tedbirlerinde devletin yetmediği alanlarda sosyal yardım cemiyetleri ve gönüllü kişilerin yardımları ile desteklenmiştir. Bu çalışmada İkinci Dünya Savaşı yıllarında artan yoksulluk sonucunda özellikle kentlerde yaşanan açlığı hafifletmeye çalışan Kızılay aş evlerinin çalışmaları dönem basınından faydalanılarak incelenmiştir.

Anahtar Kelimeler: İkinci Dünya Savaşı, Kızılay, Aşevi.

\begin{abstract}
As the effects of the world economic crisis continued in 1929, the Second World War began. This situation has led to a more intense experience of the negative economic effects of the war. During the war, the increase in military spending, the decrease in production and imports created a heavy economic burden on the people. Inflation created an economic crisis in the society, the shift of economic forces to the military area caused decreases in agricultural production, as a result of the shortage of food items, card applications began, there was a shortage of places. Turkey, which tried to remain out of war with the start of the Second World War, declared a mobilization. Although the declaration of mobilization was considered as a measure of national defense against foreign threats, it has led to a problem of occupation in the country as a result.

Various economic and social measures were taken to alleviate the economic difficulties experienced during the war. Economic interventions aimed at preventing war inflation and alleviating social problems caused by war with social policies. Social policy measures were supported with the help of social assistance societies and volunteers in areas where the state was not able to afford them. As a result increasing poverty during the Second World War yeras, the srudies of Red Crescent society soup kitchens, which try to alleviate the hunger experienced especially in cities, have been examined.
\end{abstract}

Keywords: The Second world, Red Crescent Society, Soup Kitchens.

\footnotetext{
* Bu makale “İkinci Dünya Savaşı Yıllarında Türkiye'de Ekonomik Sıkıntıların Sosyal Hayata Etkileri (1939-1945)” adlı doktora tezinden üretilmiştir. Bu tez çalışması AKÜ Bilimsel Araştırma Projeleri Koordinasyon Birimi’nce desteklenmiştir. Proje No: 13.SOS.BİL.02.

** (Dr); Afyon Kocatepe Üniversitesi, Eğitim Fakültesi, cerendemirdelen@ hotmail.com, ORCID: orcid.org/0000-0002-5911-9175

*** (Prof. Dr.) Afyon Kocatepe Üniversitesi, Eğitim Fakültesi, sortak@aku.edu.tr ORCID: orcid.org/0000-0001-9180-0158
}

Kaynak Gösterme: Ortak, Ş \& Utkugün, C. (2019). İkinci Dünya Savaşı Yıllarında Sosyal Bir Yardım Olarak Kızılay Aşevleri. Uluslararası Sosyal ve Ĕgitim Bilimleri Dergisi, 6 (12), 113-132. DOI: 10.20860/ijoses.509280 


\section{Extended Summary}

As the effects of the world economic crisis continued in 1929, the Second World War began. This situation has led to a more intense experience of the negative economic effects of the war. During the war, the increase in military spending, the decrease in production and imports created a heavy economic burden on the people. Inflation created an economic crisis in the society, the shift of economic forces to the military area caused decreases in agricultural production, as a result of the shortage of food items, card applications began, there was a shortage of places. Turkey, which tried to remain out of war with the start of the Second World War, declared a mobilization. Although the declaration of mobilization was considered as a measure of national defense against foreign threats, it has led to a problem of occupation in the country as a result.

Various economic and social measures were taken to alleviate the economic difficulties experienced during the war. Economic interventions aimed at preventing war inflation and alleviating social problems caused by war with social policies. Social policy measures were supported with the help of social assistance societies and volunteers in areas where the state was not able to afford them. As a result og increasing poverty during the Second World War yeras, the srudies of Red Crescent society soup kitchens, which try to alleviate the hunger experienced especially in cities, have been examined.

The relief axis of Red Crescent, who manages to organize in peace time as well as in wartime, is very broad. In addition to extending hands to the public at all times, military aid, prisoner aid, migrant aid, ash pits, dispensaries, hospitals, polyclinics, and mobilizing the ones are the services offered by Red Crescent. During this period, while other social assistance activities sought to alleviate poverty at normal levels, the Red Crescent sought to provide minimum conditions for the survival of the Famine-related segments and victims through emergency interventions. For this reason, one of the most basic activities during the war was to open the kitchens and distribute food and clothing to the poor. While making these contributions, Red Crescent received financial support from CHP, people's houses and wealthy sections.

With the increasing poverty during the Second World War, the Red Crescent also supported the aid activities of people affected by natural disasters that occurred frequently during the war years through vaccines and other aid campaigns. During the Second World War, One of the most basic activities of Red Crescent other than natural disaster relief was to open the kitchens and make clothing and food aid to the poor.

Red Crescent, identified with Hizir in the eyes of the people, tried to remedy the poverty of the people with his food, clothing, fuel, cleaning supplies and money. During the war, Red Crescent, who cooperated with the Ministry of National Defense, provided Civil Defence Information Services as well as clothing and cash to the soldiers. In fact, the aid materials collected by other social aid organizations have also been delivered to the unions. 
Among the services of Red Crescent are nutrition and health care services for the people who are most concerned. Health care services are offered to the poor for free hospitals, dispensaries and policlinics are at the top. Nutritionists have also opened and operated soup houses outside the time of crisis. During the wars, the migration following the wars, and during the dpal disasters, he established a soup kitchen in crisis areas and distributed food and bread to those who needed it. In addition to the extraordinary circumstances, the students and poor public calorie has distributed plenty of hot food.

The governments of the period of war, which were inadequate in the face of the cost of life caused by the Second World War and the poverty caused by the economic distress, gave Red Crescent financial support for the establishment of new soup kitchens. During these years, Red Crescent opened new kitchens and even founded mobile kitchens and tried to provide services to all the places needed. The people also helped Red Crescent in its strength. The aid were published in the newspapers of the period, and other citizens were encouraged to participate in the aid.

\section{Giriş}

11 Haziran 1868 tarihinde Osmanlı Yaralı ve Hasta Askerlere Yardım Cemiyeti adıyla kurulan Kızılay Derneği, 14 Nisan 1877'de Osmanlı Hilal-i Ahmer Cemiyeti; saltanatın kaldırılması üzerine 2 Kasım 1922'de Türkiye Hilal-i Ahmer Cemiyeti, 28 Nisan 1935'te Türkiye Kızılay Cemiyeti ve 1945 yılında da Türkiye Kızılay Derneği adını almıştır. Gerçekleşen bu isim değişiklikleri kurumun ilkeleri üzerinde hiçbir değişikliğe yol açmamıştır. Dünyada yardımın kurumlaşmasına öncülük eden Kızılhaç Derneği'nin insanlar arasında din, dil, ırk ayrımı gözetmeksizin yardımlaşma ilkeleri Kızılay'ın da parolası olmuş, kurum bu ilkeler ışı̆̆ında insanların yardımına koşmuştur (AkgünUluğtekin, 2001: 1).

Kızılay Cemiyeti'nin kuruluş amaçları şöyle belirlenmiştir: (Çapa, 2010: 19) "Kızılay herşeyden önce elindeki bütün imkanlarla savaşta ordulardaki hasta ve yaralıların tedavileriyle ilgilenerek kara ve deniz kuvvetleri sağllk heyetlerine yardımcı olacaktı. Yaralılar için savaş alanlarına yakın yerlerde karada seyyar ve sefer hastaneleri ile yardım heyetleri ve sihhiye trenleri bulunduracak, denizde ise hastane gemileri hazırlayacaktı. Herhangi bir savaş durumunda Kızılay bir yıllık gelirini aşmayacak şekilde uygun miktarda bir mablă̆ sarf edebilecekti. Cenevre ve Lahey konferanslarında alınan kararlar gereğince yabancı devletlerin muharip ordularındaki hasta ve yaralılara da yardımda bulunabilecekti." Kızılayın kuruluş amacı savaş zamanlarında yaralı ve hasta askerlere yardım etmek olmasına rağmen desteğini sadece askerlere yönelik yürütmemiştir. Kızılay savaş mağduru siviller için aşevleri ve çayhaneler açmıştır. Buralarda sayıları milyonları geçen kişileri doyurduğu gibi giyecek yardımında da bulunmuştur. Cemiyet savaşın olmadığ1 zamanlarda da önemli görevler üstlenerek deprem, yangın gibi felaketler sırasında zarar görenlere yardım elini uzatarak yaralarını sarmaya çalışmıştır. Cemiyet yardım faaliyetlerini sürdürürken gerekli malzemeleri karşılayabilmesi için maddi desteğe ihtiyaç duymuştur. Bu desteğin sağlanması 
ise halkın ilgisi ve yaptıkları bağışlarla mümkün olabilmiş; bu yüzden sık sık halkın her kesiminden yardım talebinde bulunmuştur (Sezer-Metin, 2013: 168-169).

\section{İkinci Dünya Savașı Yıllarında Türkiye’de Ekonomik Durum}

1939 yılı Eylül ayında Almanya'nın Polonya'ya saldırısıyla başlayan İkinci Dünya Savaşı, Türk ve Dünya tarihinde yoğun askeri, siyasi, ekonomik gelişme ve değişmelerin yaşandığı bir süreç olmuştur. İkinci Dünya Savaşı başta Avrupa olmak üzere, I. Dünya Savaşı'ndan sonra kurulmuş olan dünya güçler dengesinin yıkılmasına, birçok yerde siyasi haritanın bozulmasına, savaştan kaynaklanan büyük ve önemli sorunlara, yıkıntılara; bunlarla birlikte, savaş sonunda uluslararası güçler dengesinde bir boşluğun doğmasına neden olmuştur. İkinci Dünya Savaşının en önemli yönlerinden biri cephelerde süren ordular arasındaki askeri mücadelelerle sınırlı kalmayarak, cephe gerisindeki sivil insanları etkiler hale gelmesidir. Bu durum cephe gerisinde yaşayan sivil halkın gündelik yaşamını doğrudan etkilediği için sosyal ve ekonomik hayatı savaş koşullarına göre düzenlemeyi zorunlu hale getirmiştir. İkinci Dünya Savaşı süresince ve ardından yaşanan gelişmeler Türk siyasetinde, ekonomik ve toplumsal hayatta oldukça önemli değişiklikler meydana getirmiştir (Pinar, 2016: 140).

1939-1945 yılları arasında Türkiye de dünyadaki savaş ekonomisi dönemine girmiştir. Savaşa fiilen katılmamakla birlikte savaş ekonomisinin koşullarını tüm ağırlığı ile yaşamıştır. Bu dönemde iktisadi yatırımlar durmuştur. Tarım kesiminde olağanüstü vergilendirme, çalışma yaşındaki iş gücünün savaş nedeniyle silah altına alınması gibi nedenlerle üretimde önemli azalma olmuştur. Askeri harcamalar yükselmiş, devletim her türlü tüketim malından büyük miktarda satın alması yurtiçi fiyatları arttırmıştır. Üreticiler ve toptancı büyük tüccarlar stokçuluk, karaborsa gibi yollarla büyük kazançlar sağlamışlardır. Hükümet, savaştan kaynaklanan sıkıntıları hafifletmeye ve bu durumdan bazı kişilerin aşırı kazanç elde etmesini Milli Korunma Kanunu, Varlık Vergisi gibi kanunlar ve uygulamalarla önlenmeye çalışılmıştır. Devletin firsatçıları engelleme amaçlı kontrol tedbirleri durumdan faydalananları memnun etmemiş, zaten zor hayat koşullarında yaşayan halkın yoksulluğu, sıkıntıları ve dolayısıyla hoşnutsuzluğu giderek yükselmiştir (Yenal, 2013: 73-93; Pamuk, 2015: 199-208).

İkinci Dünya Savaşı yıllarının artan yoksulluk koşullarında CHP, parti teşkilatından da yararlanarak yoksullara yardım faaliyetlerini artırmıştır. 1940'lı yıllarda parti yöneticilerinin girişimleriyle il, ilçe merkez binalarında birçok yardım cemiyeti kurulmuştur. Yoksullara yardım amacıyla faaliyet gösteren Kızılay, Çocuk Esirgeme Kurumu, Yardım Sevenler Cemiyeti, Fukaraperver Cemiyetleri, Okul Çocuklarını Himaye heyetleri oluşturulmuştur (Ökte, 2018: 183). İkinci Dünya Savaşından kaynaklanan ekonomik sıkıntılarla zor durumda kalan insanlara Kızılay çeşitli şekillerde yardımda bulunmuştur.

İkinci Dünya Savaşı yıllarında artan yoksullukla birlikte; bu yıllarda sıklıkla meydana gelen deprem, sel gibi doğal afetlerden etkilenen kişilere yapılan sosyal yardım faaliyetlerine Kızılay da aşevleriyle ve diğer sosyal yardım kampanyalarıyla katkıda bulunmuştur. Kızılay'ın İkinci Dünya Savaşı'nın yol açtığı yoksulluk ve o dönemde yaşanan doğal afetler karşısında en önemli rolü, 
sorunlara acil ve geçici tedbirlerle müdahale etmek, özellikle kentlerdeki açlik tehlikesini hafifletmek olmuştur. $\mathrm{Bu}$ dönemde diğer sosyal yardım faaliyetleri normal derecelerdeki yoksulluğu hafifletmeye çalışırken, Kızılay acil müdahalelerle açlık sınırındaki kesimlerin ve afetzedelerin yaşaması için asgari koşulları sağlamaya çalışmıştır. Bu nedenle savaş boyunca en temel faaliyetlerinden biri aşevleri açmak ve yoksullara giyecek ve yiyecek dağıtmak olmuştur. Kızılay bu yardımları yaparken CHP, Halkevleri ve varlıklı kesimlerden maddi destek almıştır (Metinsoy, 2007: 349).

Kızılay yardımlarını duyurmak, halkı yardımda bulunmaya teşvik etmek adına Kızılay haftası içinde propaganda faaliyetlerini arttırmıştır. 1 Temmuz 1939'da başlayacak Kızılay haftasında Kızılay'ın savaşta ve barıșta yaptığı hizmetler, sel, yangın, deprem, salgın hastalık ve kıtlık gibi felaketlerde gösterdiği fedakarlık ve yardımların halka anlatılması için çeşitli faaliyetler yürütülmüştür. İstanbul'un her tarafına dağılmak üzere Kızılay'ın yardım şekillerini gösteren renkli afişler bastırılmıştır. Kızılay Haftası devam ettiği sürece amatör temsil heyetleri Kızılay yardımlarını gösteren temsiller vermiş, İstanbul'un tanınmış ticarethaneleri vitrinlerini Kızılay'a ayırmış, Ankara Radyosu da devamlı şekilde yayın yapmıştır (Cumhuriyet 26 Haziran 1939; Cumhuriyet 29 Haziran 1939). Kızılay Haftası münasebetiyle Kızılay Merkez Binası ile şubeleri bayraklarla süslenmiş, gece özel 1şıklandırma yapılmıştır. Birçok semtte duvarlara halkı Kızılay’a yardıma teşvik eden sözler asılmış, hoparlörlü otomobiller şehri dolaşarak Kızılay’ın büyük hizmetlerinden bahsetmiş ve Kızılay propagandası yapmıştır. Birçok sinemada da Kızılay’a üye kaydını teşvik edici yayın yapmıştır. Kızılay ev ve ticarethanelere dağıttığı belgelerle halkı Kızılay’a üye olmaya davet etmiştir (Cumhuriyet 2 Temmuz 1939; Cumhuriyet 3 Temmuz 1939).

Çocukların sosyal yardım duygularını kuvvetlendirmek amacıyla okullarda Kızılay Gençlik Kolları oluşturulmuştur. Gençlik Merkezlerine din, dil, 1rk farkı gözetmeksizin 7-18 yaş arası kızerkek öğrenciler üye olabilmiştir. Kurumun gelir kaynakları devlet yardımları, üye aidatları, yerli ve yabancı bağışları ile yardımları, malzeme, yayın satış gelirleri (şefkat pulları, okul karneleri, öğrenci belgeleri, kitaplar vb.), sosyal etkinlik gelirlerinden (sinema, tiyatro, paralı kamplar, prevantoryumlar vb.) elde edilmiştir (Cumhuriyet 5 Mart 1940; Bulut, 2007: 108). Bu teşkilatın bulunduğu okullarda öğrenciler fakir arkadaşlarının yiyecek, giyecek ve kitap gibi ihtiyaçlarını temin etmişlerdir. Maarif Vekaleti, müfettişleri okulları teftiş ederken Kızılay Gençlik Merkezlerinin faaliyetlerini de incelemekle görevlendirmiştir (Cumhuriyet 5 Mart 1940). Kızılay’ın faaliyetleri TBMM genel kurulunda da gündeme gelmiş ve çalışmalarla ilgili memnuniyet ifade edilmiştir. Örneğin Erzincan Milletvekili Behçet Kemal Çağlar gidişattan memnuniyetini 1943 Umumi Meclis Görüşmelerinde "Kızılay Gençlik Kurumlarının rapordaki ümit verici izahlara göre epeyce geliştiğini sevinçle görüyoruz. Çocuklarımızın maneviyatını yaratmakta, millet birlik ve beraberliğini küçük yaştan duymalarını sağlamakta büyük rolü olan bu kurumların daha yaygın ve başarılı olmalarını candan diliyorum" sözleriyle ifade etmiştir (Türkiye Kızılay Cemiyeti Umumi Merkezi, Umumi Meclis Zabt1, 1943; akt. Bulut, 2007: 111).

Kızılay yoksul halka yiyecek, giyecek ve para yardımları yaparak yoksulluklarını hafifletmeye çalışmıştır. 1939 yılı başında Kızılay Burdur'da fakirlere para yardımında bulunmuştur (Akşam 22 
Ocak 1939). Kızılay İzmir Merkezi yaklaşan Kurban Bayramı münasebetiyle 300 yoksul öğrenciye elbise dağıtmış, 350 yoksula elbiselik kumaş vermiştir (Cumhuriyet 2 Kasım 1939; Ulus 13 Kasım 1939). 1941 yılı başında Ankara Kızılay Merkezi Kurban Bayramında fakir halka dağıtmak üzere kurban eti kabul edeceğini ilan etmiştir. Kızılay Ankara Merkezi'nin Şefkat Yurdunda kurduğu yardıma muhtaç öğrenci ve aile aşevinden her gün 1.000 kişi yemek almıştır. 1941 yllı içinde Karadeniz Bölgesi'ndeki bazı şehirlerde iaşe darlığ 1 yaşanması üzerine ihtiyaç sahibi insanlara 90.000 liralık yardım yapılmıştır. Ankara ve İstanbul'daki okullarda fakir ve kimsesiz çocuklara 58.000 liralık yardım yapılmış, Trabzon köylerinin muhtaç halkına 2.000 lira yardımda bulunulmuştur (Ulus 6 Ocak 1941; Metinsoy, 2007: 351-352).

1942 yılı başında İstanbul Beyazıt Kızılay Şubesi bölgesindeki fakirlere 3.000 kilo kömür dağıtmış, aile başına 10 kilo kömür düşmüştür. Şubat ayı içinde Beşiktaş Kızılay Cemiyeti bölgesindeki fakir halktan 100 kişiye pirinç, sadeyağ, fasülye, mercimek, patates, soğan, sabun ve 600 kilo kömür dağıtmıştır. Çok çocuklu ve yardıma muhtaç ailelere de para yardımı yapmıştır (Vatan, 26 Ocak 1942; Vatan 13 Şubat 1942). Trabzon, Rize, Samsun, Giresun'da fakir halka kış mevsiminde bölgede ekmeklik yerine kullanılan mısır dağıtılması konusunda incelemeler yapılmış; halka 1.500 ton mısır dağıtılması kararlaştırılmışıı (Akşam, 9 Haziran 1942; Akşam 5 Temmuz 1942). 4 Mart 1943 tarihinde Antakya Kızılay Kurumu ile Yardım Sevenler ve Yoksullara Yardım Cemiyetlerinin ortak çalışmaları ile 180 öğrenciye her gün yemek verilmeye başlamıştır. Bursa halkının Kızılay’a bağışladığı parayla yoksul vatandaşlara yemek, giyim eşyası, un, ekmek dağıtılmış ve yoksul hastalar tedavi ettirilmiştir. Malatya Kızılay Kurumu da yardımda kullanmak üzere bütçesine 9.000 liralık tahsisat koymuştur (Ulus 4 Mart 1943; Ulus 8 Mart 1943; Ülkü 16 Mart 1943).

Öğrencilere yağmurluk muşamba, çorap ve yün kazak gibi kış mevsimi için gerekli eşyalar dağıtılmış, yoksul kadınlar için ise entari, yün eteklik ve kazak hazırlanmıştır. Bu gibi yardım haberlerini geniş listeler halinde Kızılay Dergisi’nden izlemek mümkündür. 1944 yılının ilk 3 ayı içinde Ankara'da muhtaçlara giyim eşyası yardımı yapılmıştır. Karadeniz Ereğli'sinde 30 Ağustos 1944 tarihinde yoksul çocuklar için geniş katılımlı bir sünnet düğünü yapılmıştır. (Akşam 29 Ekim 1943; Metinsoy, 2007: 352-353). Bursa Kızllay Merkezi Ankara Genel Merkez'den gördüğü yardımla Bursa'daki 3.000 yoksul çocuğa yemek vermeye başlamıştır. 1944 yılı Eylül ayında çalışmak zorunda kalan çocukların iaşelerinin temin edilerek okul ihtiyaçları karşılanmıştır. Kızılay'ın ilkokul çocuklarına yaptığı yardımın genişletilmesi kararlaştırılmıştır (Cumhuriyet 17 Ocak 1944; Akşam 21 Eylül 1944).

Kızılay; yoksulluğun ve sabit ve dar gelirlilere yönelik sosyal yardım faaliyetlerinin arttığı 1943 yılında Ankara Halkevi Sosyal Yardım Şubesine 500 lira yardım yapmış, İzmir Veremle Mücadele Derneği'ne 30.000 lira bağışlamıştır. Savaş döneminde artış gösteren verem hastalı̆̆ıyla mücadele kapsamında İstanbul Üniversitesine 1.000 lira yardımda bulunmuş, üniversite harici veremli yüksek okul öğrencilerinin tedavileri için 1.000 lira tahsis etmiştir. İzmir Kızılay Merkezi idaresindeki dispanserlerde birçok veremli hasta muayene edilmiştir. Çocuk Esirgeme Kurumuyla beraber yoksul ve kimsesiz çocuklar sünnet ettirilmiş̧ir. Ayrıca Kızılay askeri seferberlikle birlikte artan 
asker sayısı nedeniyle devlete önemli bir maddi yük bindiren askerlerin giyim eşyası konusunda devlete destek olmuş ve vatandaşı orduya yardım konusunda bilinçlendirerek kampanyalarla giyecek eşya ve bağış toplamıştır. 160.175 liralık para bağışı ile ordu için temin edilen bağış toplamı yaklaşık 1 milyon lirayı geçmiştir (Metinsoy, 2007: 353-354). Savaş yıllarında Kızılay Milli Müdafaa Vekaleti'ne de yardımcı olmuştur. Bu yardımların başında sivil savunma bilgilendirme hizmetleri, erlere sağladığı giysi ve nakit para yardımları gelmektedir. 1941 yılında erlere tutarı 894.384,95 lirayı bulan yün fanila, kazak, çorap, eldiven ve giyecek eşyası yardımı ile birlikte 160.175,25 liralık para yardımı yapmıştır. Bu dağıtım 1942'de de sürmüş, Kızılay Milli Müdafaa Vekaleti'ne erlere dağıtılmak üzere 304.516,11 lira tutarında giyecek eşya yardımı yapmıştır (Akgün-Uluğtekin, 2001: 249).

Kızılay sadece yoksullara değil doğal afetlerden zarar gören insanlara da yardım etmeye çalışmıştır. Savaş döneminde Türkiye birçok deprem, sel ve heyelan gibi doğal afetleri yaşadığı için doğal nedenlerden kaynaklanabilecek muhtemel sosyal sorunların ve hoşnutsuzlukların önünü almak ve açlık, salgın hastalık gibi risk unsurlarını ortadan kaldırmak açısından Kızılay’ın acil yardımları ayrı bir önem kazanmıştır. Kızılay doğal afetlerden zarar gören insanlara yaptığı yardımlara maddi destek sağlamak için basına "Yurttaş! Felaketzedelere yardımın az bile olsa çöken bir çatıya sende bir çivi çakabilirsin, yardımını esirgeme”; "Yurttaş vaktinde yardıma koş, felaketzedelerin yarasını daha sıcak iken sar." gibi ilanlar vermiştir (Ulus 2 Aralık 1943; Ulus 3 Aralık 1943; Metinsoy, 2007: 353). Kızılay deprem, sel, heyelan, kuraklık ve yangın gibi doğal afet bölgelerine yardım götürmüş, faaliyetleri basında geniş bir şekilde yer almıştır. Ayrıca tüm ülke çapında yardım kampanyaları açarak halkı bilinçlendirmiş ve yardıma davet etmiştir (Cumhuriyet 25 Eylül 1939; Ulus 25 Eylül 1939; Cumhuriyet 30 Aralık 1939; Akşam 30 Aralık 1939; Ulus 30 Aralık 1939; Ulus 31 Aralık 1939; Ulus 4 Ocak 1940; Cumhuriyet 1 Ocak 1940; Akşam 7 Ocak 1940; Cumhuriyet 5 Ocak 1941; Cumhuriyet 15 Şubat 1941; Cumhuriyet 14 Şubat 1941; Cumhuriyet 9 Mart 1941; Cumhuriyet 23 Eylül 1941; Cumhuriyet 24 Eylül 1941, Cumhuriyet 27 Eylül 1941, Cumhuriyet 30 Eylül 1941; Cumhuriyet 4 Temmuz 1942; Tekeli-İlkin, 2014: 112; Akgün-Uluğtekin, 2001: 189, 194-195; 198-201; 227-228; 232-233).

\section{Kızılay'ın Aşevleri Vasıtasıyla Yaptığı Yemek Yardımları}

Kızılay'ın sunduğu pek çok hizmet arasında halkı en çok ilgilendirenler her zaman için beslenme ve sağlığa yönelik hizmetler olmuştur. Beslenme deyince ilk akla gelen kriz zamanları dışında da açılıp işletilen aşevleridir. Kızılay Cemiyeti savaşlarda, savaşları izleyen göçler sırasında veya doğal afetlerde kriz bölgelerinde aşevi kurarak ihtiyacı olanlara yemek ve ekmek dağıtmayı görev kabul etmiştir. Ancak olağanüstü durumlar dışında da öğrencilere ve yoksul halka kalorisi bol ve sıcak yemek dağıtmak Kızılay’ın başarıyla sürdürdüğü faaliyet olmuştur. Büyük kentlerde veya taşrada kurulan Kızılay mutfakları kapılarını düzenli veya düzensiz olarak yemek için başvuran yoksullara açık tutmuştur (Akgün-Uluğtekin, 2001: 243).

Kızılay’ın sosyal yardım alanındaki en önemli faaliyeti aşevleri kurulması olmuştur. Aşevleri İkinci Dünya Savaşı döneminde artan yoksulluk ve deprem felaketleriyle birlikte faaliyete geçmiştir 
(Metinsoy, 2007: 349). İkinci Dünya Savaşı'nın oluşturduğu hayat pahalılığı ve ekonomik sıkıntının birkaç misline çıkardığı yoksulluk karşısında yetersiz kalan devlet bu dönemde bir kez daha Kızılay ile işbirliği yapmış, açlığı önleyebilmek için yeni aşevleri kurması için Kızılay'a maddi destek vermiş̧ir. Bu yıllarda Kızılay halka sıcak yemek dağıtmak üzere yeni mutfaklar açmış, hatta gezici mutfaklar kurarak gerek duyulan her yere hizmet götürmeye çalışmıştır (Cumhuriyet 1 Şubat 1941; Akgün-Uluğtekin, 2001: 244).

1942 yılında savaş sıkıntılarının en çok açlık şeklinde yansıdığı İstanbul'da yoksul öğrencilere erzak ve yakacak dağıtmak ve yoksul halka her gün sıcak yemek vermek üzere aşevi kurmak için 7 kişilik komite oluşturulmuştur. Komite yoksulların saptanması ve gıda dağıtımı işlerini yürütmüştür. Aşevlerinin ayrıca bir komite merkez bürosu ve ücretli olarak çalışan memur ve hizmetlileri olmuştur (Akgün-Uluğtekin, 2001: 244). Yoksullara ve o dönemde sık sık karşılaşılan büyük kayıplara neden olan deprem mağdurlarına aşevlerinde yemek dağıtılmıştır. Kızılay aşevleri kurulmadan önce de fakirlere yiyecek, giyecek, para gibi yardım faaliyetlerinde bulunmuştur. 1942 yılında Mayıs ayı itibariyle fakirlere para, yiyecek ve giyecek olarak 4.900 liralık yardım yapılmıştır. Veremlilere 1.082 lira ve gıdasız çocuklara 27.212 liralık yardım yapmıştır. $\mathrm{Bu}$ yardımların 1942 ve 1943'de artan darlıklar ve yoksulluk karşısında yetersiz kalması üzerine Kızılay 1943 'ten itibaren yardım faaliyetlerini arttırmıştır. Bu seferki faaliyet, insanlar için asgari yaşama koşulu olan açlı̆̆ın giderilmesi olmuştur. Kızllay Dergisi'nde "Yiyecek noksanlı̆̆ ve pahalıllğgn birçok fakir aileyi müşkül duruma düşürdüğü için" gelecek kış Kızılay'ın İstanbul'da fakir halka yardım etmeye başlayacağı, belirli bölgelerde açılacak aşevlerinde yoksulların doyurulacağı duyurulmuştur (Metinsoy, 2007: 349).

Savaş dolayısıyla gıda maddeleri fiyatlarının artışı yoksul aileleri zor duruma sokmuş, kışın gıda maddelerinin azlığı bu zorluğu bir kat daha arttırmıştır. Ticaret Vekaleti ve Kızılay Genel Merkezi 1943 kışı için yoksul aileleri sevindirecek önemli bir karar vermiştir. Öncelikle yalnız İstanbul'da uygulanmak üzere parasız yemek verecek aşevleri açılması çalışmaları başlatılmıştır. $\mathrm{Bu}$ aşevlerinin İstanbul'un çeşitli semtlerinde açılacağı ve yoksul ailelerin buralardan hazır yemek alabilecekleri belirtilmiştir. Kızılay idaresi aşevlerinin yerlerini tespit edilip gerekli malzemelerin süratle teminine başlamıştır (Vatan 24 Mayıs 1942). Aşevlerinin öncelikle İstanbul, Ankara, İzmir, Edirne ve Bursa'da, tercihen fakir mahallelerde açılması planlanmış ve gerekli hazırlıklar yapılmıştır. Hükümet ve Kızılay diğer illerde de aşevi açabilmek için incelemelerde bulunmuş ve bazı yerlerde seyyar aşevi usulünün uygulaması düşünülmüştür (Vatan 3 Haziran 1942).

Kızılay İstanbul Temsilciliği aşevleri kurulması için hazırlıklara başlamış, öncelikle Edirnekapı, Topkapı, Kasımpaşa, Eyüp, Üsküdar ve Beşiktaş semtlerinde açılması kararlaştırılmıştır. Birkaç seneden beri Eyüp, Haseki, Laleli ve Üsküdar'daki Ahmediye İmaretinde her gün 1.250 fakire sıcak yemek dağıtan Evkaf İdaresi'nin teşkilatından istifade edilerek harekete geçilmiştir. Eski imaretlerin kullanılmayan kazan ve mutfak aletlerinden elde kalanların kullanılması imkanları araştırılmıştır. Kızılay İstanbul temsilcisi Cemal Okan bu konuda basına şu bilgileri vermiştir (Cumhuriyet 5 Haziran 1942; Vatan 6 Haziran 1942): 
"Hakiki muhtaçlarl tespit etmek üzere aşevi kurulacak bölgelerde kaymakamların reisliğinde Kızılay ve Parti temsilcileri ile ilkokul başöğretmenlerinin katılımı ile muhtaç cetvellerini hazırlamak üzere komisyon toplanacaktır. Aşevlerine verilecek gıda maddelerini stok etmek üzere Çırağan Sarayında bir depo tesisini düşünüyoruz. Bundan başka her bölgede birer tali depo da bulundurulacakttr. Şimdiden kati bir rakam söylenemez ise de 30.000 muhtaca günde bir defa sicak yemek verilecektir."

Ülkeye getirilmesi düşünülüp sonradan vazgeçilen Yunan çocuklar için yapılan hazırlıklar bazı şehirlerde açılacak aşevlerine sarf edilmiştir (Cumhuriyet 6 Haziran 1942). İstanbul ve ülkenin gerek duyulan yerlerinde aşevleri oluşturularak fakir halka parasız yemek dağıtılması hazırlıkları ilerlemiş, Kızılay ile Evkaf İdaresi'nin işbirliği yapabileceği bildirilmiştir. Evkaf İdaresi'nin Eyüp, Üsküdar ve Haseki'deki günde 600 öğünlük yemek dağıtan imarethanelerinin genişletilmesine; Çapa, Topkapı, Kasımpaşa, Beşiktaş bölgesinde de aşevleri açılmasına karar verilmiştir. Eylül'ün 15 'ine doğru yemek dağıtımına başlanması ve ilk hamlede öğlen 10.000 fakire günde bir öğün yemek verilmesi kararlaştırılmıştır. Alınacak sonuca göre teşebbüsün genişletilebileceği, gerekirse yaz mevsiminde de yemek dağıtımına devam edileceği bildirilmiştir (Akşam 5 Temmuz 1942; Vatan 6 Temmuz 1942).

Evkaf ve Kızılay, İstanbul'un fakir semtlerinde çok sayıda insana hizmet edebilecek genişlikte aşevleri kurmaya karar vermiştir. Üsküdar, Fatih, Aksaray, Beşiktaş, Eyüp'te birer aşevi açılacağı, aşevlerinde Evkaf ve Kızılay'ın sıcak yemek dağıtacağı, kışın fakir halka yardım edileceği bildirilmiştir. İstanbul'da günde bir defa 10.000 kişiye yemek verilebileceği, Ankara'da da fakirlere yemek verilmesi için tedbirler alındığı belirtilmiştir (Akşam 8 Eylül 1942; Akşam 19 Eylül 1942; Akşam 27 Eylül 1942).

Aşevlerinde yemek yiyecek yoksul halk için fakirliklerini zabıta incelemesi ile belgelemeleri şartı getirilmiş̧ir (Cumhuriyet 26 Ekim 1942; Cumhuriyet 28 Ekim 1942). Her ilçenin 2.000-5.000 fakir vatandaş tespit edeceği, yalnız bu tespit edilenlere yemek verileceği ilan edilmiştir (Akşam 14 Kasım 1942). 1942 yılı sonunda Kızılay'ın fakir halka vereceği sıcak yemek için açılan aşevlerinin miktarı ve açılacak aşevlerinde kaç kişinin sıcak yemek yiyebileceği hakkında defterler hazırlanmıştır. Hükümet ve Parti kanallarınca yapılan incelemeler sonucunda tespit maksadıyla hazırlanan cetvellerin önemli bir kısmı Kızılay aşevleri komitesine gönderilmiş, yemek alacak kişilere tebligat yapılmış ve yemek kuponlarının dağıtımına başlanmıştır.

İstanbul'da yemek dağıtımından yararlanacak kişilerin sayısı 1942 yılı Kasım ayı itibariyle 16.300 olarak tespit edilmiştir. Bu sayının tespitinde "Parti ve zabıta kanalları ile yapılan incelemeler hakiki fakirlerin sıhhatle meydana çıkarılmasını mümkün kıldı̆̆ı ve bu sayede muhtaç olmayan kimselerin haksız yere aşevlerinden istifade etmelerinin önüne geçilmiş bulunduğu" belirtilmiştir. Kızılay aşevlerindeki yemek dağıtımı için günde 4.000 lira harcanacağı hesaplanmış ve Cemiyetin bu teşebbüsünü öğrenen bazı tacirler Kızılay'a başvurarak yardım yapmaya başlamışlardır. Aşevleri komitesi reisi İstanbul Milletvekili Saadettin Uras yardımlar devam ederse aşevleri sayısının arttırılacağını söylemiştir (Cumhuriyet 25 Kasım 1942; Ulus 28 Kasım 1942). 
Aşevlerine CHP Genel Merkez ve Hükümetin parasal desteği de ulaşmıştır. CHP Genel Merkezi aşevlerine her yıl 135.000 lira ayırmış, Hükümet değişen rakamlarda katkı yapmıştır. Aşevlerine tüccar kesimden de yardım etmeleri istenmiş, bu teklife Ticaret Vekaleti olumlu cevap vermiş̧ir. Vekaletten alınan cevaba göre aşevleri 700.000 liralık tahsisat ile idare edilmiş, tahsisatın 100.000 lirası Ticaret Odas1 ve diğer 100.000 lirası da Ticaret ve Zahire Borsası tarafından temin edilerek, geriye kalan 500.000 lira ilgili daire tarafindan verilmiştir (Akşam 5 Kasım 1942; AkgünUluğtekin, 2001: 245). Aşevleri ilk gündeme geldiğinde İstanbul Ticaret Odası da Zahire Borsası ile birlikte gelir fazlasından 200.000 lira bağışlamıştır. Ayrıca Ticaret Odası tüccarların aşevlerine yardım etmesi için çalışmıştır. Ticaret Vekaletince Ticaret Odası ile Ticaret Borsası tarafından aşevlerine 100'er bin lira verilmesi uygun görülmüş, 200.000 lira Kızılay'ın kasasına yatırılmıştır. Kızılay aşevleri için geniş oranda yardım gördügünnden fakirlere yardım işi o oranda geniş tutulmuş ve bu teşebbüs verimli olmuştur (Akşam 18 Kasım 1942; Cumhuriyet 11 Aralık 1942; Metinsoy, 2007: 350).

Dönemin gazeteleri incelendiğinde aşevlerinin faaliyete geçtiğine dair haberler yer almaktadır. Örneğin Akşam Gazetesinin 1 Aralık 1942 tarihli nüshasında İstanbul'un çeşitli noktalarında kurulan aşevlerinin yemek dağıtmaya başlayacakları duyurulmuştur. İstanbul'da Karagümrük, Topkapı, Eyüp, Beşiktaş, Üsküdar ve Laleli'de açıldığı; Kasımpaşa'da açılmak üzere olduğu ve aşevlerinin her aileye nüfus miktarına göre yemek vereceği belirtilmiştir (Akşam 1 Aralık 1942). Aşevlerinde açıldığı ilk gün kavurmalı bulgur pilavı dağıtılmış; sonraki günlerde nohut, fasulye, mercimek, patates yemeklerinin de verileceği bildirilmiştir. Kızılay aşevlerinden yemek alacak muhtaçlara nüfuslarına göre 1'den 5 kişiliğe kadar karneler verilmiş, karnesini mutfak gişesine gösterenin kabı büyük kepçelerle doldurulmuştur. Aylık karne ücreti 30 kuruş olarak belirlenmiş, bir gün için alınan yemek 1 kuruşa gelmiş, bu 30 kuruşu veremeyecek halde olanların karne paraları Kızılay idarelerince verilmiştir. Așevleri semtlerdeki bakımsız durumda olan ve Kızılay'ın tamir ettirdiği cami ve medreslerde açılmıştır (Akşam 2 Aralık 1942). (Bknz. Ek 1/2/3)

Kızılay aşevleri komitesi uzun zaman ihtiyaca yetecek miktarda kavurma, bulgur, patates, mercimek, fasulye, nohut, zeytinyağı ve sadeyağ stok etmiştir. Kızılayın aşevleri kanalıyla yaptığı yemek yardımları halkın beslenme ihtiyacına cevap vermiş, halkın kuruma olan itimadı artmıştır. Aşevlerinden uzak bölgelerde oturan muhtaçlara yemek dağıtılması konusunda yemeklerin seyyar kazanlarla taşınması ve dağıtılması kararlaştırılmış, dağıtım yerlerinin tespit ve temini ise kaymakamlara bırakılmıştır (Cumhuriyet 3 Aralık 1942; Akşam 5 Aralık 1942; Cumhuriyet 5 Aralık 1942).

Kurum fakir öğrencilere de farklı bir yöntemle yemek yardımı yapmayı kararlaştırmış, 3.400 fakir öğrenciye yemek verme hazırlıklarına başlamıştır. Yemek için erzağın okul idarelerine verilmesi, okulların yemek pişirerek muhtaç öğrencilere dağıtması kararlaştırılmış̧ır. Yemek yardımının üniversiteli muhtaç öğrencilere yayılması da düşünülmüş, üniversite teşekküllerinin pişirme ve dağıtmayı taahhüt ettikleri takdirde Kızılay erzak verebileceğini ilan etmiş̧ir (Akşam 2 Aralık 1942). İmam, bekçi gibi aylık alan bazı kimselerin Kızılay aşevlerinden yararlandıklarına dair basında şikayet yazısı çıkması üzerine Kızılay aşevleri komitesi şikayetlerin yersiz olduğunu 
belirtmiştir. Mahallelerde aşevlerinden yemek alacak fakirlerin tespitini Kızılay müessesesi üzerine almamış, bu vatandaşlar parti ve zabıta tarafından yapılan incelemeler sonucunda tespit edilmiştir (Cumhuriyet 11 Aralık 1942). (Bknz Ek 4)

1942 yılı sonunda İzmir'de 3 semtte muhtaç halka sıcak yemek dağıtmak üzere aşevi açılmış ve ilk yemek olarak etli fasülye dağıtılmıştır. Her biri 1.000 kişiye yemek dağıtacak olan bu aşevlerinde ilk yemeğin dağıtımına vali ve CHP müfettişi, belediye ve parti idare heyetleri reisleri ve Kızılay basın temsilcileri de bulunmuştur. 17 Aralık 1942 tarihli Akşam Gazetesi'nde Kızılay aşevlerine halkın yardımını ve desteğini sağlamak amacıyla şöyle bir ilan yer almıştır: "Vatandaş bugün en büyük hayır Kızılay aşevlerine yardımdır. Canlı cansız kurbanlarınızı makbuz mukabilinde teslim ediniz." (Cumhuriyet 11 Aralık 1942; Akşam 17 Aralık 1942).

24 Aralık 1942 tarihinde İstanbul'da açılan aşevlerinin yedincisi ve sonuncusu olan Kasımpaşa aşevi kapılarını fakir halka açmıştır. Aşevleri komitesi reisi Kasımpaşa aşevinde 2.000 fakire yemek dağıtılmak üzere tertibat alındığını ve bu suretle İstanbul'da açılan 7 aşevinde sıcak yemek dağıtılan fakirlerin sayısının 15.000'i bulduğunu, ayrıca 4.500 lise öğrencisi ve Maltepe, Kartal, Bakırköy ve diğer semtlerdeki fakir halktan 1.000 kişi ile aşevlerinden yardım görenlerin sayısının 20.000'e yükseldiğini söylemiştir. Lise ve ortaokullara Kızılay depolarından yiyecek gönderilmesine başlanmış ve fakir öğrencilerin ay başından itibaren okullarda pişirilen sıcak yemekten faydalanabilecekleri belirtilmiştir. Kızılay aşevleri komitesinin yemek dağıtımında gösterdiği başarıyı Cumhurbaşkanı İsmet İnönü takdirle karşılamış ve aşevlerini ziyareti esnasında komite reisi İstanbul Milletvekili Saadettin Uraz'a memnuniyetini bildirmiştir. Maltepe'de bir aşevi daha açılmış ve aşevi açılışının Maltepe'de büyük sevinç uyandırdığı basında yer almıştır (Cumhuriyet 24 Aralık 1942; Cumhuriyet 28 Aralık 1942).

Bakırköy'de açılan aşevinde her gün 500 yoksula sıcak yemek verilmiş, bu rakamla Kızılay'ın İstanbul'da her gün doyurduğu yoksul sayısı 21.900'a çıkmışır. Kurum Genel Merkezi faaliyette bulunan aşevi ve öğrenci sofralarındaki 6.000'i aşkın mevcudu çoğaltmak amacıyla 100.000 liralık yardımda bulunmaya karar vermiş ve bu paranın 60.000 lirasını göndermiş, kalanını da ihtiyaçlara göre göndereceğini açıklamıştır (Ulus 4 Ocak 1943; Ulus 21 Ocak 1943). 1943 yılı başında İzmir'de Kızılay'ın 4 aşevi olduğu ancak sayının 9'a çıkarılması ve 15.000 kişiye hergün yemek verilmesi hedeflenmiştir. Bir yıl sonrasında ise Kızılay İzmir Merkezi'nin açtı̆̆ 7 aşevinde yaklaşık 10.000 vatandaşa sıcak yemek dağıtılmıştır (Akşam 15 Ocak 1943; Ulus 15 Ocak 1943; Cumhuriyet 16 Ocak 1944).

İstanbul'da aşevleri Hükümetin dar gelirlilere ve yoksullara yardım politikası ile 1943 yılının Ocak ayında da faaliyete devam etmiştir. Üsküdar, Laleli, Eyüp, Karagümrük, Topkapı, Kartal ve Beşiktaş’ta açılan ilk aşevlerinde Ocak ayı içinde 16.300 insana sıcak yemek verilmiştir. Kızılay aşevleri kısa zamanda yayılarak İstanbul'un yaklaşık 20 semtinde faaliyet göstermeye başlamıştır. $\mathrm{Bu}$ aşevlerinde her gün 5.000'den fazla vatandaşa sıcak yemek dağıtılmıştır. Kızılay İstanbul dışında İzmir, Ankara, Edirne, Kırklareli, Tekirdağ, Bursa, Samsun, Trabzon, Kahramanmaraş, 
Malatya, Zonguldak ve Sivas gibi kent merkezlerinde de aşevleri kurmuştur (Metinsoy, 2007: 350351).

Kızılay Genel Merkezi Edirne şubesine 20.000 lira göndermiş, bu yardımla ve Edirne'de temin edilecek diğer yardımlarla Edirne'de 4 aşevi açılacağı, Sanatlar Okulunda açılacak aşevi ile okullardaki muhtaç öğrencilere sıcak yemek verileceği duyurulmuştur. Edirne'deki aşevleri muhtaç ve yoksul öğrencilere sıcak yemek dağıtımına başlamıştır. İstanbul'da 1943 yılında 7.449.164 kap yemek, 1944 y1lında 8.080.662 ve 1945 yılında 7.268.232 kap yemek dağı̆tılmıştır (Ulus 20 Ocak 1943; Ulus 24 Ocak 1943; Akgün-Uluğtekin, 2001: 245- 246).

Aşevlerinden istifade edecek olanları Hükümet ve CHP tespit etmiş, hazırlanan listelere göre yemek verilecek olanlara karne veya kuponlar dağıtılmıştır. Kızılay bu listelere göre her gün yemek vermiş̧ir. Yemekler göre belirli gramajda ekonomik bir şekilde sunulmuştur. Genelde verilen yemekler zeytinyağlı fasulye, fasulye, kavurmalı nohut, mercimek, bulgur pilavı idi. Nüfus başına verilen bir kepçe bulgur pilavı 150 gram bulgur, 10 gram kavurma, 10 gram sadeyağ içermiştir. Ayrıca her yemekte adam başına 10 gram soğan, 300 gram odun, 7 gram tuz, 4 günde 1 gram sabun, 4 gram da soda sarf edilmiştir (Metinsoy, 2007: 350-351). Açlık gibi büyük bir felaketi önlemek amacıyla çalışmaya başladıklarından aşevlerinde yemek yiyenlere birer kap yemek verilebilmiştir. Savaş bittikten sonra aşırı yoksulluklar yavaş yavaş kaybolmaya başlayınca aş ocaklarında 1950 yılı başında etli yemek ve tatlı verilmeye başlanmış ancak bu uygulama Kızılay'ın o yılın doğal afetlerine de yetişmesi gerektiğinden ancak 5 ay sürdürülebilmiştir. Bundan sonra eski sisteme dönülmüş bir başka deyimle açlığı önlemek esas alınmıştır. Kızılay aşevlerine çeşitli kesimlerden yapılan büyük yardımlara karşın 1944 yılında bir kap yemek ancak 12.15 kuruşa mal edilmiştir (Akgün-Uluğtekin; 2001: 244, 246).

1943 Şubat'ında Kızılay Ankara Merkezince idare edilen Şefkat Yurdu aşevinde 180'den fazla muhtaç vatandaşa her gün öğle yemeği verilirken Kızılay Ankara Merkezi tarafından bu yardım genişletilmiştir. Muhtaçlar mahalle, ocak birlikleri vasıtasılya tespit edilmiş, bu şekilde toplanan beyannameleri inceleyerek geliri olmayan fakir vatandaşlardan 320 kişiyi de yemek verilen kişiler rasına dahil edilmiş, böylelikle hergün 500 kişiye sıcak yemek dağıtılmıştır (Ulus 5 Şubat 1943). Kızılay tarafından mütevazi bir bütçe ile idare edilen Ankara Aşevi çeşitli sebepler yüzünden kapanmak üzere iken Kızılay Ankara Merkezi, Ankara Ticaret Odasından yardım talep etmiştir. Ankara tacirleri Kızılay aşevinin kapanmaması ve yardımın devam etmesi için 26.000 lira taahhüt etmişlerdir. Gaziantep'te de yemek verilen 230 öğrenciden başka muhtaçlara sicak yemek vermek üzere masrafları hayırsever vatandaşlar ve CHP tarafından karşılanan bir aşevi açılmıştır (Ulus 16 Şubat 1943; Ulus 5 Mayıs 1943).

26 Temmuz 1943 tarihinde Kızılay aşevlerinin faaliyetinin genişlemesi ve yardımların çoğaltılması için yeni kararlar alınmıştır. Edirnekapı, Eyüp, Topkapı ve Laleli aşevlerine ilaveten Kadıköy ve Feriköy'de aşevi açılması kararlaştırılmıştır (Cumhuriyet 26 Temmuz 1943). 2 Ağustos 1943 tarihinde Feriköy'de aşevi açılmıştır. Geniş ölçüde fakir halkla meskun olan bu semtin büyük bir ihtiyacına cevap veren aşevi açıldığı gün 2.000 kişiye sade yağlı bulgur pilavı dağıttmıştır. $\mathrm{Bu}$ 
aşevi ile birlikte Kızılay'ın İstanbul'da yemek verdiği kişi sayısı 25.000'e varmıştır. Ağustos sonlarına doğru Kadıköy ve civarı fakir halkı için 9. aşevinin açılacağı ve 1.000'den fazla fakire yemek dağıtılacă̆ ilan edilmiştir. 16 Ağustos 1943 tarihinde bahsedilen aşevinin açılmasını bölgedeki fakir halk sevinçle karşılamıştır. Yemeğini almak için gelemeyeceklerin hakları evlerine gönderilmiş, yoksul kimselerin evlerine yemek gönderilmeye başlanmıştır (Cumhuriyet 2 Ağustos 1943; Cumhuriyet 16 Ağustos 1943).

İstanbul'da 1943 yılı eğitim öğretim dönemi başlangıcında üniversitedeki aşevinden başka lise ve ortaokul öğrencilerine de sıcak yemek dağıtılmasına devam edilmiştir. Kızılay önceki eğitim öğretim döneminde olduğu gibi 1943 yılında da okullardaki fakir öğrencilere yemek vereceğini duyurmuştur. Kızılay ortaokullardaki öğrencilere sıcak yemek verebilmek için okullardan bu öğrencilerin listesini istemiştir (Cumhuriyet 2 Ağustos 1943; Akşam 5 Eylül 1943; Cumhuriyet 6 Eylül 1943) .

Kızılay aşevlerinin yazın da fakir halka yemek dağıtmaya devam edebilmesi için Hükümet Kızılay emrine vermek üzere tahsisat ayırmıştır. Kızılay Merkez Şubesi aşevlerinin yaz mevsiminde de faaliyetine devam etmesi için aşevlerine yardım göndermiş ve fakirlere yemek verilmesini sağlamıştır. Bunun için Edirne'ye 10.000, Tekirdağ'a 7.500, Kırklareli’ne 5.000, Trabzon'a 7.500, Zonguldak'a 10.000, İzmir aşevlerine de 25.000 lira yardım yapılmıştır. Trabzon'da açılan aşevlerine 17.500 lira, Bursa aşevlerine 23.000 lira ve Sivas aşevlerine 2.000 lira verilmiştir. $\mathrm{Bu}$ yardımlarla birçok şehirdeki aşevleri yaz aylarında da faaliyetlerini sürdürmüştür (Akşam 15 Nisan 1943; Akgün-Uluğtekin; 2001: 249).

Kızılay İstanbul'un çeşitli semtlerinde açtığı aşevlerinde sıcak yemek vererek binlerce fakir halkı doyurmuştur. Ancak elindeki gelir kaynakları yetmediğinden aşevlerinin kapanmaması için 1942 yılında Maliye 1.5 milyon lira sarf etmiştir. 1943 yılında erzak ve diğer malzeme fiyatları önceki yıla göre pahalılaşmıştır. Yapılan hesaplara göre bir fakirin aşevinden doyabilmesi için ayda 10 liraya ihtiyaç vardır. Masrafların birkaç misli artması üzerine 1943 yılında aşevlerinin kapanmasına meydan vermemek üzere Kızılay yeni gelir kaynakları aramaya başlamıştır. İstanbul'daki tüccar, esnaf ve zenginlerin yardımına müracaat edilmesi, şehrin zenginlerinin parti merkezine davet edilerek aşevlerinin devamını temin etmek ve 1944 kışında fakirlere sabun, yakacak dağıtabilmek üzere yardım yapmaları istenmiştir. Diğer taraftan CHP ilçe merkezlerinde Kızılay temsilcisinin de kayılımıyla yapılan toplantıda her bölgedeki esnaf zümreleri çağırılarak yardımlarına müracaat edilmiştir. Bir fakirin iaşesi Kızılay’a senede 120 liraya mal olduğundan her esnafin en aşağı bir fakirin iaşesini üzerine alması ve senede 120 liradan aşağı olmamak üzere taahhütte bulunması istenmiştir. Bu amaçla Beşiktaş parti merkezine firıncı, kasap ve bakkallar davet edilmiş, firıncılar 500-600 lira vermeyi taahhüt etmiştir (Akşam 15 Kasım 1943). Ticaret vekili Behçet Uz, Kızılay İstanbul aşevleri idare komitesinin kış mevsimi faaliyetinin ana çizgileri ile düşüncelerinden bahsederek aşevlerinin kuruluşunda 15.000 yoksula yemek vermek üzere kurulmuş iken sonraları yardımın genişletilerek 20.000 kişiyi geçtiğini söylemiştir. 1944 kışı için yemek dışında sabun ve çamaşır gibi yardımlar yapılması da kararlaştırılmıştır. Bunun için 1 milyon 
liraya ihtiyaç olduğunu belirten Behçet Uz bağış yapan müessese ve vatandaşlara şükranlarını bildirmiş, bütün İstanbulluları yardıma katılmaya davet etmiştir (Cumhuriyet 16 Kasım 1943).

18 Eylül 1943 tarihinde İstanbul Vilayet Merkezinde Ticaret Vekili Behçet Uz başkanlığında, çalışamayacak fakirlere ve kimsesiz çocuklara yapılacak yardım şeklini tespit etmek üzere bir toplantı yapılmıştır. Toplantıda yoksullara aşevlerinden yemek verilmesi, çamaşır ve sabun temini gibi Kızılay'ın yapacağı yardımlara Parti ve Halkevi teşkilatının her semtte ve herkesin gücü ölçüsünde yardımını temin etmek için çalışılması kararlaştırılmıştır. Bu yardım teşkilatına diğer hayır cemiyetleri de katılarak çamaşır dikimi gibi katkılarda bulunmuşlardır (Akşam 18 Eylül 1943; Metinsoy; 2007: 350).

16 Kasım 1943 tarihinde Ticaret Vekili Behçet Uz'un verdiği bilgiye göre İstanbul'da yardıma muhtaç fakirlerin sayısı 40.000-50.000'i bulmuş, bunlardan ancak 30.000'ine Kızılay'ın açtığ aşevlerinden yiyecek verilmiştir. Bu 30.000 kişiye çamaşır ve sabun dağıtılması için ihtiyaç duyulan 1.000.000 lirayı temin etmek için zenginlerin yardımına müracaat edilmiştir. Bu müracaat üzerine Kızılay'a teslim edilen para miktarı 300.000 lira olmuş ve para yardımından başka yiyecek maddesi olarak da bağışlar kabul edilmiştir. "İstanbul zenginlerinin kuru ekmek bulmaktan aciz şehrin fakirlerinin göz yaşların silecek fedakarlıklardan çekinmeyecekleri" ifade edilmiştir. Her ilçede yoksulların sayısı belli olduğu için bağışa katılanlar kaç fakirin iaşesini üzerlerine aldıklarını kaydetmişler, bir sene devam edecek yardım için bazıları senelik bağış miktarını bir defada vermişler, bazıları da taksitlerle ödemeyi taahhüt etmişlerdir. Kızılay'ın aldığı sabun ve çamaşırlar aş ocaklarından yemek alanlara ihtiyaçları derecesine göre dağıtılmıştır (Akşam 16 Kasım 1943; Akşam 7 Aralık 1943).

Kızılay aşevleri İstanbul'un ileri gelen sanayici ve tüccarları tarafından finanse edilmiş̧ir. 1944 Ocak ayına kadar CHP İstanbul merkezi aşevlerine 460.000 lira yardımda bulunmuştur. 1943 sonunda aşevlerinin genişletilmesi ve 30.000 yoksula yemek verme kapasitesine ulaşması için vatandaşların yardımını istenmiş ve çok sayıda kişi yardımda bulunmuştur. 1944 yılında Ticaret Odası ile Ticaret Borsası'nın 600.000 lira yardım yapacağı belirtilmiştir. Örneğin Adana'da bir aşevi açılmış, aşevi heyetine fabrikatör ve çiftçiler seçilmiştir. Kızılay'a bağışta bulunanların listeleri gazetelerde yer almıştır. Bunlar arasında da önemli sayıda tüccar ve sanayici vardır (Akşam 18 Eylül 1943; Metinsoy; 2007: 350).

1944 yılı başında İstanbul aşevleri için CHP İstanbul İl Merkezinde kurulan yardım komitesinin temin ettiği yardım miktarı 480.000 lirayı bulmuş, bu paradan başka Ticaret Odası ve Ticaret Borsası'nın 100.000'er lira ve Esnaf Odasının 10.000 lira vermesi, İthalatçı ve ihracatçı birliklerinin 100.000 lira vermesi kararlaştırılmıştır. Aşevlerine yapılan yardımlar hamiyet yarışı olarak nitelendirilmiş ve Kızılay aşevlerinden İstanbul'da 27.000 fakire sıcak yemek verildiği daha 20.000 kişinin yemek almak için sıra beklediği ifade edilmiştir (Cumhuriyet 24 Ocak 1944; Cumhuriyet 26 Ocak 1944). 11 Şubat 1944 tarihinde komite 800.000 lira bağış toplamıştır. Yardımlar şu cümlelerle açılanmıştır (Cumhuriyet 11 Şubat 1944): 
"Çallşamayacak vaziyette bulunan ve günlük yiyeceğini temin edemeyen İstanbullulara yemek temini için faaliyette bulunan Klzllay aşevlerine İstanbul'un hamiyetli halkı büyük bir insaniyet hissi ile teberrularda bulunmaktadır. Kendisinden 10.800 lira istenen bir Türk firmasının bu miktara hiç itiraz etmeden verecek parası olmadĭ̆ l fakat yeni getirttiği yün ipliklerinden 10.800 liralık miktarını vermeye amade olduğunu bildirmesi hamiyete bir misal olarak kaydedilmektedir."

1944 yazında Kızılay aşevlerinden çıkan yemekler hakkında basında eleştiriler yer almıştır. Akşam Gazetesi incelediği Kızıltoprak aşevinin yemekleri ve mutfak temizliğini mükemmel bulduğunu belirtirken, Yeni Sabah Gazetesi Laleli aşevinde pişen bulgur pilavının ağza alınmayacak ve bulgur olduğu seçilemeyecek berbatlıkta olduğunu yazmıştır. Bir Kızılay temsilcisinin "Yemek dağıtımını kesme zamanı gelmiştir, sızlltılar bıkkınlıktan ileri gelmiştir" yorumu üzerine aşevlerinde yapılan yemek dağıtımı hakkında 26 Temmuz 1944 tarihli Akşam Gazetesinde şu yorum yer almıştır (Akşam 26 Temmuz 1944): "Yemek dağıtımını kesmek yerine çoğaltmak zamanı gelmiştir. Pahalılık artmıștır. Sizıltılar bıkkınlıktan doğuyorsa bile bıkkınlığı gidertecek çeşitlilikler müdürlerin zekasından fişkırmalıdır. Memleketin nimetleri çeşitleri çoğaltmaya da müsaittir. “

Basında Laleli aşevinde 23 Temmuz 1944'te dağıtılan bulgur pilavının yenilemeyecek derecede olduğundan ve Kızılay temsilcisinin beyanatından bahseden Yeni Sabah Gazetesi'nin 25 Temmuz 1944 tarihli yazısı üzerine Kızılay Cemiyeti İstanbul aşevleri idare komitesi iddiaları yalanlayan bir açıklama yayınlamıştır (Akşam 30 Temmuz 1944).

1944 yılında Kızılay'ın İstanbul'un çeşitli semtlerinde açtığı 16 aşevinde her gün 21.933 kap yemek dağıtılmıştır. 1943 yılında her ilçede CHP kanalıyla nakdi bağışta bulunmuş, bu maksatla partide toplanan bağış miktarı 780.000 lirayı bulmuştur. Parti bu paranın 100.000 lirasını Halkevleri sosyal yardım komitelerinin emrine tahsis etmiş, komiteler kendilerine verilen bu parayı çevrelerindeki yoksulların himayesine sarf etmişlerdir. Bu bağış sisteminden iyi sonuç alındığından 1944 yılı için de aynı sistemin uygulanması kararlaştırılmıştır (Akşam 21 Eylül 1944).

Kızılay öğrencilerin beslenmelerini temin etmek amacıyla da aşevleri açmıştır. "Öğrencilerin daha iyi çalışması ve daha verimli olması için” yoksul öğrencilere İstanbul Üniversitesi avlusunda bir aşevi açmıştır. Aşevi Kızılay bayraklarıyla donatılmış, açııış gerçekleştirildikten sonra evde 1.200'den fazla öğrenci yemek yemiştir (Metinsoy; 2007: 351-352). 4.000 ortaokul ve lise öğrencisine yapılacak yardım şekli de tespit edilmiş, Kızılay'ın verdiği gıda maddelerinden yapılan yemek dağıtılacağı ve dağııımın bütün okullarda aynı anda başlanacağı bildirilmiştir (Cumhuriyet 31 Aralık 1942). 1943 eğitim öğretim döneminde üniversite aşevi tekrar faaliyete geçmiş, üniversite öğrenci birliği tarafından yeni bir bina yapılan aşevinde her gün 1.000 öğrenciye öğle yemeği verilmiş̧ir. 1944 yılı başında Kızılay aşevi fakir üniversite öğrencilerine gündüz yemeklerinin aynısı ve 22 kuruş karşıllğıında akşamları da yemek vermiş̧tir (Cumhuriyet 16 Kasım 1943; Akşam 2 Ocak 1944). 
Kızılay yardımları savaş döneminde artan yoksulluğu görünür kılması açısından sembolik bir önem taşımaktadır. Aşevlerinden yararlananların durumu acıklı manzaralar oluştururken artan yoksullaşmayı göstermiştir. Birçok yoksul insan aşevlerinden bakır çalmış, bazıları yemek almak için kabı olmadığından kevgir hatta çay ibriği getirmiş, bunları bulamayan yoksul insanlar ise elinde bir kağıtla sırada beklemiştir. Yemek verilirken kendilerine yemek veren aşçıya dua etmişler, bazı insanlar kabı olmadığı için kağıda konulan yemeğini alır almaz eliyle yemiştir (Akgün-Uluğtekin; 2001: 249).

\section{Sonuç}

İkinci Dünya Savaşı yıllarında artan yoksullukla birlikte savaş yıllarında sıklıkla meydana gelen doğal afetlerden etkilenen kişilere yapılan yardım faaliyetlerine Kızılay da aşevleri ve diğer yardım kampanyaları ile destek olmuştur. Kızılay’ın sosyal yardım alanındaki en önemli faaliyeti aşevleri kurmak olmuştur. İkinci Dünya Savaşı boyunca Kızılay'ın doğal afet yardımlarından başka en temel faaliyetlerinden biri aşevleri açmak ve yoksullara giyecek ve yiyecek yardımı yapmak olmuştur. Halkın gözünde Hızır ile özdeşleşen Kızılay yaptığı yiyecek, giyecek, yakacak, temizlik malzemesi ve para yardımları ile halkın yoksulluğuna çare olmaya çalışmıştır.

Kızılay'ın hizmetleri arasında halkı en çok ilgilendirenler her zaman için beslenme ve sağlığa yönelik hizmetler olmuştur. Beslenme denilince de akla ilk gelen kriz zamanları dışında da açılıp işletilen aşevleri olmuştur. Savaşlarda, savaşları izleyen göçlerde ve doğal afetlerde kriz bölgelerinde aşevi kurarak ihtiyacı olanlara yemek ve ekmek dağıtmıştır. Olağanüstü durumlar dışında da öğrencilere ve yoksul halka kalorisi bol sıcak yemek dağıtmıştır. Şehirlerde genellikle fakir mahallelerde kurulan Kızılay aşevleri kapılarını düzenli veya düzensiz olarak yemek için başvuran yoksullara açık tutmuştur.

İkinci Dünya Savaşından kaynaklanan hayat pahalılığı ve ekonomik sıkıntının oluşturduğu yoksulluk karşısında yetersiz kalan savaş dönemi hükümetleri yeni aşevleri kurması için Kızılay'a maddi destek vermiştir. Halk da Kızılay'a gücü ölçüsünde yardımda bulunmuştur. Yapılan yardımlar dönemin gazetelerinde özellikle yardım eden kişilerin isimleriyle yayınlanmış, diğer vatandaşların da yardıma katılması teşvik edilmeye çalışılmıştır.

Savaş nedeniyle gıda maddelerinin fiyatlarının artması yoksul aileleri zor duruma düşürmüş, kışın gıda maddelerinin azlığı bu zorluğu bir kat daha arttırmıştır. Bu yıllarda Kızılay yeni mutfaklar açmış hatta gezici mutfaklar kurarak ihtiyaç duyulan her yere hizmet götürmeye çalışmıştır. Kızılay yardımları savaş döneminde artan yoksulluğu görünür kılması açısından da önem arz etmektedir. Aşevlerinden yararlananların durumu acıklı manzaralar oluştururken artan yoksullaşmayı göstermiştir. Birçok yoksul insan aşevlerinden bakır çalmış, bazıları yemek almak için kabı olmadığından kevgir hatta çaydanlık getirmiş, bunları bulamayan yoksul insanlar ise elinde bir kağıtla sırada beklemiştir. Yemek verilirken kendilerine yemek veren aşçıya dua eden insanlar, kabı olmadığı için kağıda konulan yemeğini alır almaz eliyle yiyen insanlar olmuştur. Kızılay'ın aşevleri kanalıyla yaptığı yemek yardımları dar gelirli halkın beslenme ihtiyacına cevap vermiş, halkın kuruma olan itimadı artmıştır. Ancak bu yardımlar ekonomik sıkıntı yaşayan halk için gündelik bir çözüm olmuş, halkın çektiği ekonomik sıkıntıyı engelleyememiştir. 


\section{Kaynakça}

\section{Süreli Yayınlar}

Akşam Gazetesi

Cumhuriyet Gazetesi

Tan Gazetesi

Ulus Gazetesi

Ülkü Dergisi

Vatan Gazetesi

\section{Kitap ve Makaleler}

Akgün K, Seçil ve Murat Uluğtekin; (2001). Hilali Ahmer'den Kızılay’a, Türk Hava Kurumu Basımevi, Ankara, C. II.

Bulut, Taner; (2007). Cumhuriyet' in Bir Gençlik Projesi Olarak Kızılay Kampları (1936-1950), Çağdaş Türk Tarihi Araştırma Dergisi, VI/14, ss: 103-135.

Çapa, Mesut; (2010). Kızılay (Hilal-i Ahmer) Cemiyeti (1914-1925), Türkiye Kızılay Derneği Yayınları.

Metinsoy, Murat; (2007). İkinci Dünya Savaşı'nda Türkiye Savaş ve Gündelik Yaşam, Homer Kitapevi, İstanbul 2007.

Ökte, Sezai Kürşat; (2018). İstanbul İlkokullarında Okuyan Yoksul Çocuklara Yardım Cemiyetleri Birliği (1940-1947), Ankara Üniversitesi Türk İnkılap Tarihi Enstitüsü Atatürk Yolu Dergisi, S. 62, ss: 181-198.

Pamuk, Şevket; (2015). Türkiye’nin 200 Yıllık İktisadi tarihi, Türkiye İş Bankası Yayınları, İstanbul.

Pinar, Mehmet; (2016). İkinci Dünya Savaşında Kızılay’ın Dış Yardımları ve Yardımların Dış Politikaya Etkileri, Route Educational and Social science Journal, 3 (1), ss: 139-158.

Sezer, Cemal ve Ömer Metin; (2013). Balkan Savaşlarından Milli Mücadeleye Hilal-i Ahmer Cemiyeti'nin Yardım Faaliyetleri (1912-1922), Ankara Üniversitesi Dil, Tarih Coğrafya Fakültesi Tarih Araştırmaları Dergisi, 32/54, ss: 167-182.

Tekeli, İlhan ve Selim İlkin; (2014). Savaşın İçinden Geleceğine Yönelen İkinci Dünya Savaşı Türkiye'si, C. III, İletişim Yayınları, İstanbul.

Yenal, Oktay; (2013). Cumhuriyet'in İktisat Tarihi, Türkiye İş Bankası Yayınları, İstanbul. 
Ekler

\section{Kızlay aşevleri dün açıldı}

Ístanbul balıkçiığında rekor: Dün 320,000

nutedair kanun tayihasi carder.

Suikast dâvâsınz bugün bakılacak

çift torik tutuldu, halka ucuz balık dağıtıldı

Anitara, 1 (Vatan) - Yartn sabah

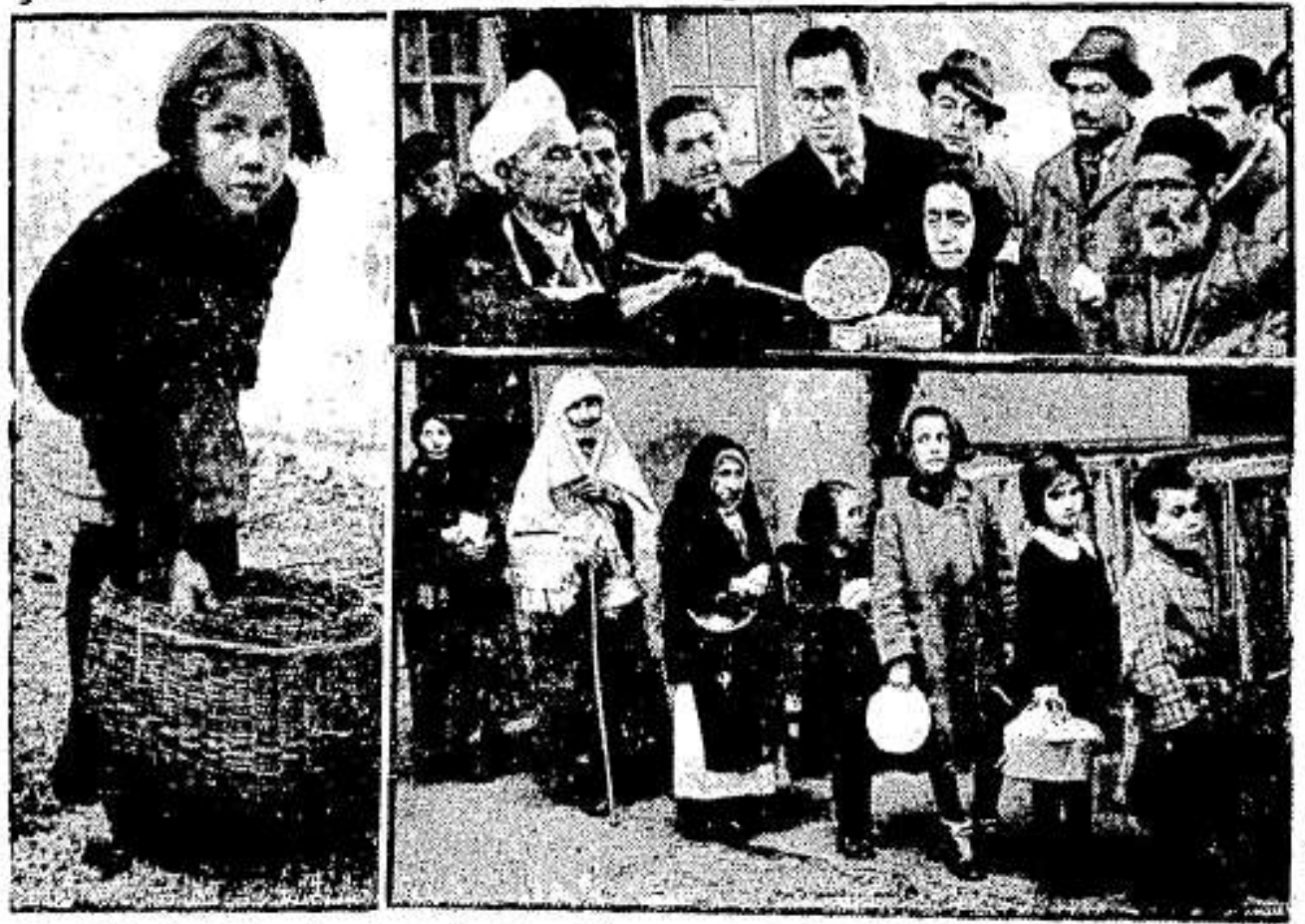

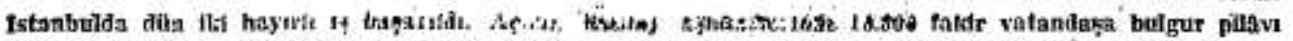

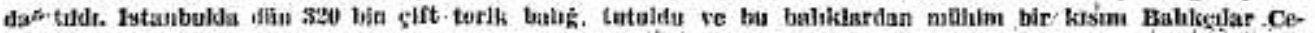

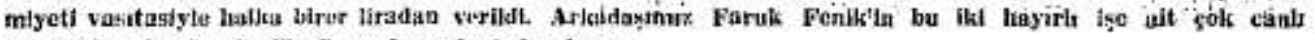
róportajiat bugith dertwistcü suyfasmzda bulaiakstbiz.

Ek 1 : Vatan Gazetesi, 2 Aralık 1942. 


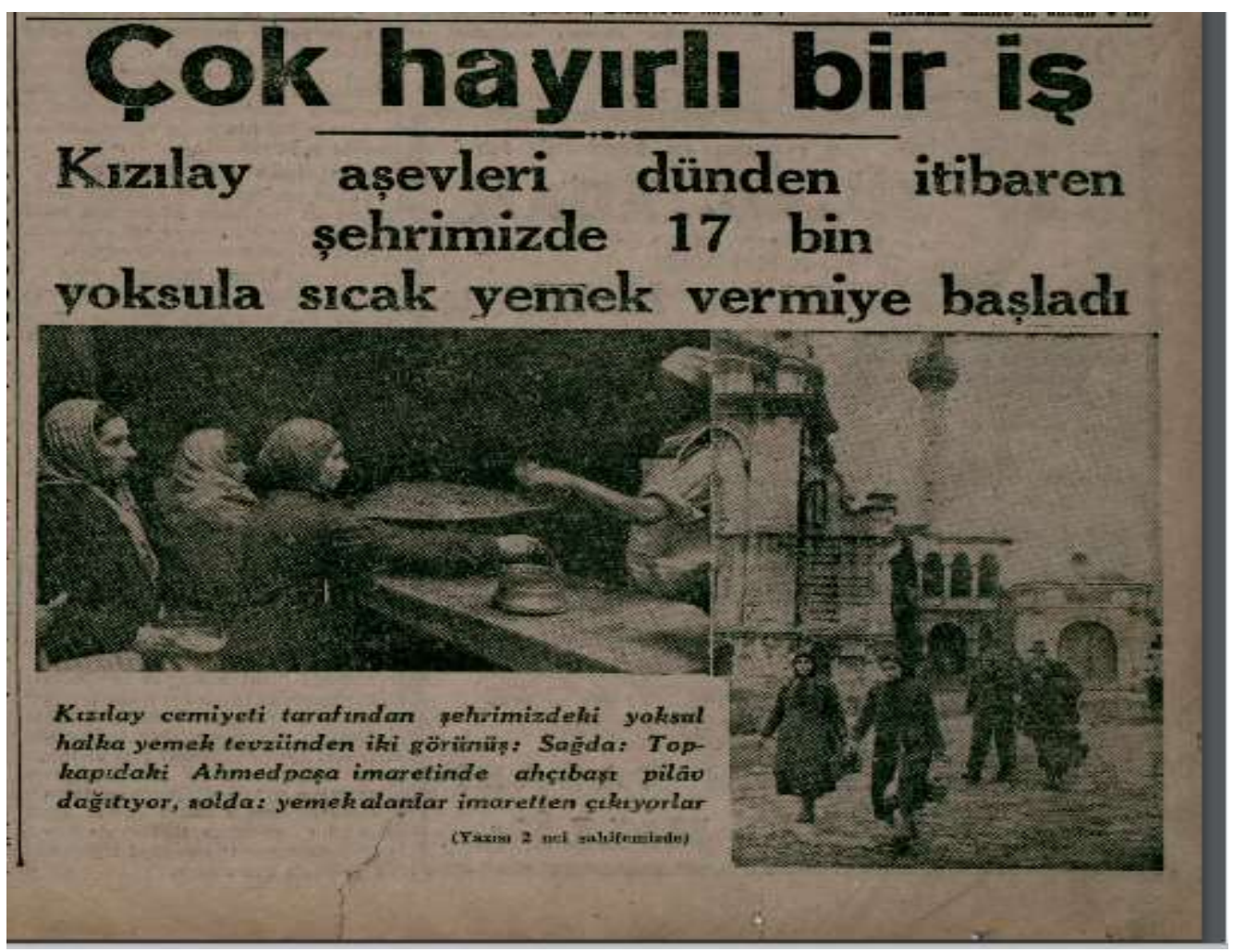

Ek 2: Cumhuriyet Gazetesi, 2 Aralık 1942.

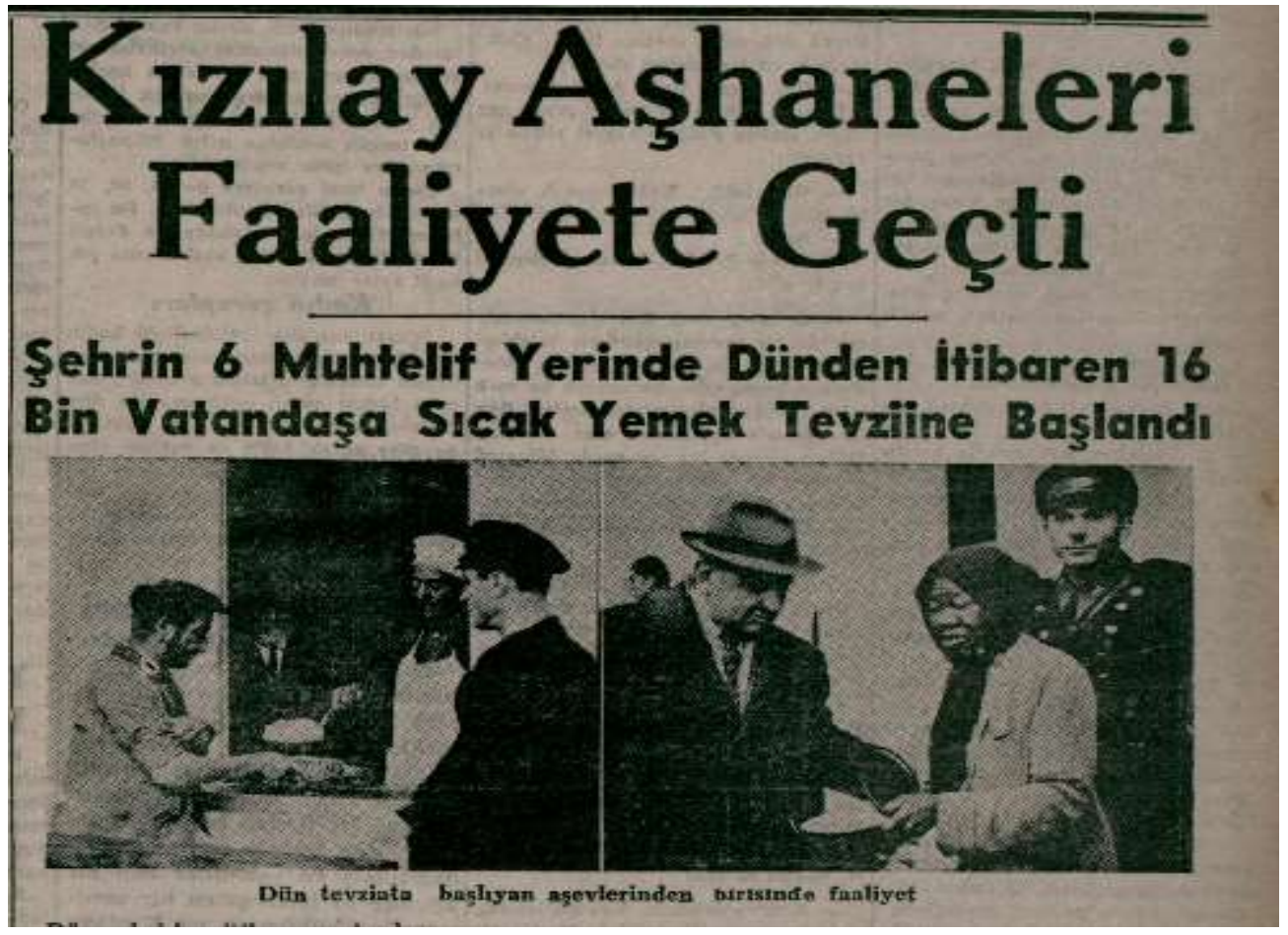

Ek 3: Tan Gazetesi, 2 Aralık 1942. 


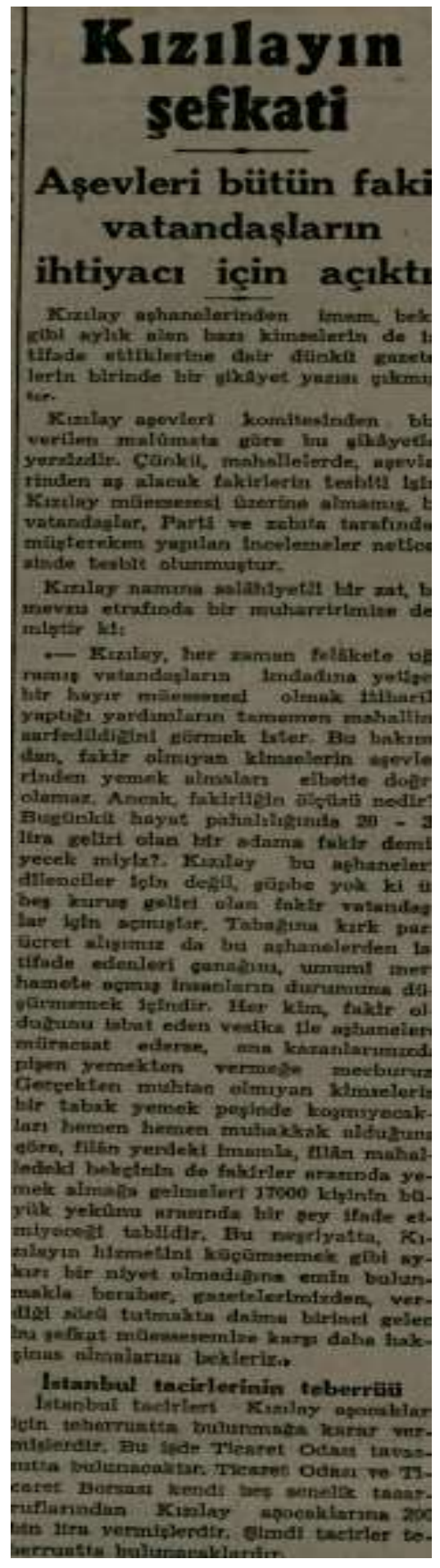

Ek 4: Cumhuriyet Gazetesi, 11 Aralık 1942. 